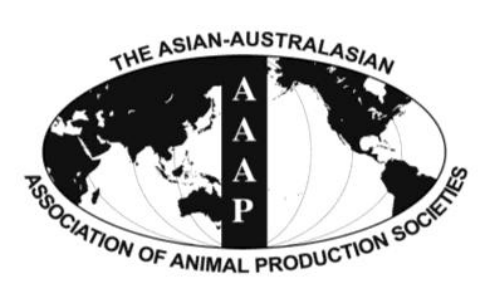

Open Access

Asian Australas. J. Anim. Sci.

Vol. 28, No. 3 : 382-390 March 2015

http://dx.doi.org/10.5713/ajas.13.0620

pISSN 1011-2367 elSSN 1976-5517

\title{
Growth Performance, Carcass Yield, and Quality and Chemical Traits of Meat from Commercial Korean Native Ducks with 2-Way Crossbreeding
}

\author{
K. N. Heo ${ }^{\mathrm{a}}$, E. C. Hong ${ }^{\mathrm{a}}$, C. D. Kim, H. K. Kim, M. J. Lee, H. J. Choo, H. C. Choi, \\ M. M. H. Mushtaq, R. Parvin, and J. H. Kim* \\ Poultry Science Division, National Institute of Animal Science, RDA, Cheonan 331-808, Korea
}

\begin{abstract}
This work was conducted to investigate the performance and meat characteristics of commercial Korean native duck (KND). A total of 180 1-d-old ducklings of 2-way crossbreds from A and B lines (from National Institute of Animal Science) were used in this work and divided into 4 groups ( 3 replicates/group, 15 birds/replicate). The four groups were 4 crossbreds as AA (A line [ 9 ] $\times A$

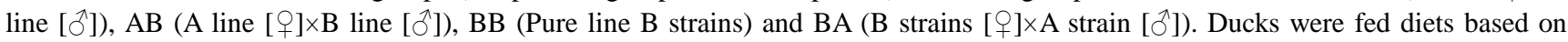
corn-soybean meal for 0 to $3 \mathrm{wk}(22.4 \%$ crude protein [CP], 2,945 kcal/kg metabolizable energy [ME]) and 3 to $8 \mathrm{wk}(18.4 \% \mathrm{CP}, 3,047$ $\mathrm{kcal} / \mathrm{kg} \mathrm{ME}$ ). As a result of this study, average body weight of 4 crossbreds were $625,1,617,2,466$, and 2,836 g at 2, 4, 6, and 8 weeks, respectively, and significantly increased over the period of time $(\mathrm{p}<0.05)$. Body weight of BB group was greater than other crossbreds at the age of 6 weeks $(\mathrm{p}<0.05)$. There was a significant difference in weekly body weight gains $(\mathrm{p}<0.05)$, which were $573,991,850$, and $371 \mathrm{~g}$ at $2,4,6$, and 8 weeks old, respectively. Uniformity of 4 crossbreds was $84.9 \%, 80.5 \%$, and $72.5 \%$ at 6,7 , and 8 weeks, respectively, and there was no difference among crossbreds. Body weight gain of BB crossbred was highest among crossbreds ( $<<0.05$ ). Weekly feed intake significantly increased with weeks as $669,1,839,2,812$, and 3,381 g at 2, 4, 6, and 8 weeks respectively (p<0.05). Feed intakes of AA and BB crossbreds were higher at 2 to 4 weeks old than others and that of BB crossbred was highest at 4 to 6 weeks old ( $\mathrm{p}<0.05$ ). Weekly feed conversion ratios were $1.17,1.86,3.32$, and 9.37 at 0 to 2,2 to 4,4 to 6 , and 6 to 8 weeks old, respectively, and it increased with age $(\mathrm{p}<0.05)$. There was no significant difference in feed conversion ratio among crossbreds. Carcass yields of 4 crossbreds were $73.6 \%, 71.6 \%, 73.5 \%$, and $71.7 \%$, respectively, so there was no significant difference among crossbreds. There was no difference in wing, neck, breast and leg ratios among crossbreds. However, back ratios of 4 crossbreds were $17.6 \%, 18.0 \%, 15.8 \%$, and $17.6 \%$, respectively, and back ratio of BB was the highest among crossbreds. Finally, these results may provide the basic data on the production, carcass quality, fatty acid and amino acid composition of commercial KND with 2-way crossbreeding. (Key Words: Carcass Quality, Growth Performance, Korean Native Duck)
\end{abstract}

\section{INTRODUCTION}

Ducks are one of the fastest growing and efficient producer of animal protein and can weigh over $3 \mathrm{~kg}$ in 42 days (Adeola, 2003). In Korea, duck meat is known as a healthy food and has a unique meat flavor and texture (Kim et al., 2012). Duck meat contains higher essential fatty acids such as linoleic and linolenic acids when compared to other meats (Kim et al., 2011; NIAST, 2011). Duck meat is also

\footnotetext{
* Corresponding Author: Ji-Hyuk Kim. Tel: +82-41-580-6712, Fax:+82-41-580-6719, E-mail: jihyuk@korea.kr

${ }^{a}$ First two authors equally contributed to this work.

Submitted Oct. 2, 2013; Revised Dec. 16, 2013; Accepted Sept. 22, 2014
}

good for the prevention of diseases such as arteriosclerosis or hypertension by inhibition of cholesterol formation and stimulating blood circulation in the body (Kang et al., 2006; NIAST, 2011).

Most of the breeding ducks reared in Korea are imported Peking duck breed from England and France. The official process of importing an animal breed is complicated and sometimes imports are limited when avian influenza occurs in exporting country. In addition, imported breeds are expensive and their breeding and management facilities including feeding program, disease control and biosecurity are not well established in Korea. Moreover, developed countries are trying to tighten their regulations and laws

Copyright @ 2014 by Asian-Australasian Journal of Animal Sciences This is an open-access article distributed under the terms of the Creative Commons Attribution Non-Commercial License (http://creativecommons.org/licenses/by-nc/3.0/), which permits unrestricted non-commercial use, distribution, and reproduction in any medium, provided the original work is properly cited. 
regarding genetic resource management and conservation. On this background, the importance of keeping and managing indigenous genetic resources and development of the breed at the national level is magnified.

Korean Native duck (KND), a domestic breed, has approximately less than $10 \%$ market share in Korea. Furthermore, the productivity of KND is low due to disorganized and unsystematic inbreeding. To overcome this issue, the National Institute of Animal Science (NIAS) in Korea planned to develop the improved breed of KND and distributed the male of this breed in 2010. The NIAS will distribute improved male and female KND at the end of this year. Furthermore, the NIAS will conduct groundwork for commercial native duck production by establishing a breeding program. At the first stance, the present project was conducted to provide the basic data for commercial native duck production by investigating the performance of 2-way crossbreeding from native duck strain A and B (Hong et al., 2012; Kim et al., 2012) as breeding ducks.

\section{MATERIALS AND METHODS}

\section{Birds, experimental design and diets}

Ducks that were bred over 7 generations in Korea are called KND. Large-type KND had been collected and made homogeneous by the NIAS since 2010. Two pure-lines (A and $\mathrm{B}$ line) of KND were housed in the NIAS research farm in 2013. In this experiment, a total of $180 \mathrm{KND}$ ducklings crossbred from these lines were divided into four groups (three replicates per crossbred, 15 birds per replicate) under completely randomized design. Four crossbreds were as

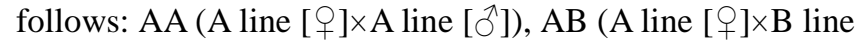

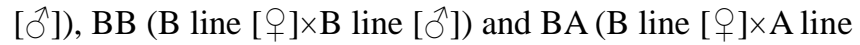
[ठ]]). They were fed corn-soybean meal based diets for eight weeks with starter diets from 0 to $3 \mathrm{wk}(22.4 \%$ crude protein [CP], 2,945kcal $/ \mathrm{kg}$ metabolizable energy [ME]) and grower diets from 3 to $8 \mathrm{wk}(18.4 \% \mathrm{CP}, 3,047 \mathrm{kcal} / \mathrm{kg} \mathrm{ME}$; Table 1) as suggested by Korean Feeding Standards for Poultry (KFSP, 2007). Feed and water were offered ad libitum throughout the experimental period.

\section{Housing and management}

House temperature was maintained at $32^{\circ} \mathrm{C}$ for first 3 days and thereafter was reduced about $3^{\circ} \mathrm{C}$ to $5^{\circ} \mathrm{C}$ per week to attain about $24 \pm 2.5^{\circ} \mathrm{C}$ temperature. The brooding chamber humidity was maintained at $60 \%$ to $70 \%$ and lighting management was adjusted to $17 \mathrm{~L}: 7 \mathrm{D}$ except for the first three days $(23 \mathrm{~L}: 1 \mathrm{D})$. A 5-10 cm thick rice husk as litter material was used on the floor. Other specifications for house management were carried out in accordance with the practices of the Committee on Animal Research and Ethics, National Institute of Animal Science, Rural Development Administration, Korea.
Table 1. Formula and chemical composition of basal diet

\begin{tabular}{lcc}
\hline Item & 0 to 3 weeks & 3 to 8 weeks \\
\hline Ingredients (\%) & 54.50 & 61.05 \\
Corn & 2.50 & 10.30 \\
Wheat bran & 37.75 & 18.10 \\
Soybean meal & 1.50 & 7.00 \\
Corn gluten meal & 0.50 & 1.00 \\
Soybean oil & 0.45 & 0.70 \\
Limestone & 1.40 & 1.00 \\
Dicalcium phosphorus & 0.10 & 0.05 \\
DL-methionine & 0.05 & 0.05 \\
L-lysine & 1.00 & 0.50 \\
Vit.-Min. premix ${ }^{1}$ & 0.25 & 0.25 \\
Salt & 2,945 & \\
Chemical composition (\% or otherwise stated $)^{2}$ & 3,047 \\
ME (kcal/kg) & 22.4 & 18.4 \\
CP & 0.44 & 0.39 \\
Methionine & 1.27 & 0.86 \\
Lysine & 0.76 & 0.66 \\
Ca & 0.46 & 0.35 \\
P & &
\end{tabular}

ME, metabolizable energy; CP, crude protein.

${ }^{1}$ Provided following nutrients per $\mathrm{kg}$ of diet: vitamin A, 1,175,000 IU; vitamin $\mathrm{D}_{3}$, 225,000 IU; vitamin E 1,900 IU; vitamin $\mathrm{K}, 891 \mathrm{mg}$; vitamin $\mathrm{B}_{1}, 50 \mathrm{mg}$; vitamin $\mathrm{B}_{2}, 2,250 \mathrm{mg}$; vitamin $\mathrm{B}_{6}, 750 \mathrm{mg}$; vitamin $\mathrm{B}_{12}, 600$ $\mathrm{mg}$; Ca-pantothenate, 2,500 mg; niacin, $15,400 \mathrm{mg}$; biotin, $110 \mathrm{mg}$; folic acid, $30 \mathrm{mg}$; Co, $50 \mathrm{mg}$; Cu, 1,750 mg; Mn, 36,000 mg; Zn, 24,000 mg; I, $600 \mathrm{mg}$; Se, $25 \mathrm{mg}$.

${ }^{2}$ Analyzed values.

\section{Growth performance}

The body weight gain (BWG) was measured after every two weeks. The feed was withheld for 2 hours before weighing the birds. Feed intake (FI) was also measured for the same period and was divided by BWG to calculate the feed conversion ratio (FCR). Livability represented the ratio of the number of live birds to the number of all birds at each week.

\section{Uniformity}

After measuring the body weight (BW) of all the ducks in each replicate, uniformity was evaluated with the ratio of the number of ducks that weighed an average (of each replicate) plus or minus $10 \%$ range to the number of all ducks (of each replicate).

\section{Carcass yield and meat quality}

Three ducks of average weight from each replicate were randomly selected for carcass evaluation and meat quality analysis. For this purpose, these ducks were anesthetized with diethyl ether and killed at the end of $8 \mathrm{wk}$. Carcass yield was calculated by dividing carcass weight (flesh plus bones) by live weight (by removing head, viscera and foot weights). Meat cut ratio of 5 five parts viz. wings, back, neck, breast and legs, was calculated by dividing it with live 
weight, and then ratio of each part was calculated. The breasts were placed in plastic bags and refrigerated $\left(4^{\circ} \mathrm{C}\right.$ to $\left.6^{\circ} \mathrm{C}\right)$. At the laboratory, the samples were frozen at $-18^{\circ} \mathrm{C}$ until they were analyzed.

\section{Laboratory analysis}

Meat color: The color of each meat sample was determined using a Chroma meter (Minolta CR300, Konica Minolta, Osaka, Japan), designed by Commision Internationale de Leclairage as lightness ( $\mathrm{L} *$ ), redness ( a $*$ ), yellowness ( $\mathrm{b} *$ ) values according to a Standard Edition $\mathrm{Y}=92.40, \mathrm{x}=0.3136, \mathrm{y}=0.3196$ (Park et al., 2007).

Shear force measurement: The Warner-Bratzler (WB) measurement was performed for shear force using nine meat samples from each crossbred. At room temperature, samples (strips with $19 \mathrm{~mm}$ width) were sheared perpendicular to the longitudinal orientation of the muscle fibers by a TA-XT Plus Texture Analyzer (Stable Micro Systems, Surrey, UK) fitted with a $30 \mathrm{~kg}$ load cell and Texture Exponent 32 version 3.0.3.0 software. A TA-7 WB shear type blade was used. Test settings included a button type trigger, $55 \mathrm{~mm}$ travel distance, $4 \mathrm{~mm}$ per second test speed and calibration return distance of $1 \mathrm{~mm}$. The maximum force measured to cut the strips was expressed in $\mathrm{kg} / \mathrm{cm}^{2}$. For each breast muscle, one strip was sheared in 2 locations and the strip heights at each shear point was recorded and used for data analysis (Zhuang et al., 2007).

Water holding capacity: The water holding capacity was evaluated 5 hours after slaughter, using the methodology described by Hamm (1961). The evaluation is based on measuring water loss when a pressure is applied to the muscle. The $0.5 \mathrm{~g}$ meat cubes of each of nine meat samples were placed between two filter papers and two glass plates, and a 10-kg-weight was placed on the top of the glass plate for $5 \mathrm{~min}$. The difference in the breast muscle weight before and after the procedure represents the water loss. The results were expressed as percentage of exudated water in relation to the initial sample weight.

Cooking loss: The cooking loss was determined five hours after slaughter in an oven pre-warmed to $170^{\circ} \mathrm{C}$. Nine breast muscle samples from each crossbred were weighed and put in trays with aluminum grills previously dried in an incubator. The trays were placed inside the oven until the sample core temperature reached $75^{\circ} \mathrm{C}$. Samples were cooled at room temperature; re-weighed and cooking loss was calculated as the difference between the initial and the final sample weights (Chae et al., 2011).

Meat $\mathrm{pH}$, water, protein, and ash contents: The $\mathrm{pH}$ of breast meat samples was measured just after slaughtering by using a Deep Carcass $\mathrm{pH}$ meter (pH-K21, Carometec $\mathrm{GmbH}$, Lünen, Germany). The water, protein and ash contents were measured by the AOAC method (AOAC, 2005) using nine samples per crossbred. Five grams of minced meat from each sample were dried in an aluminum pan at $100^{\circ} \mathrm{C}$ for $18 \mathrm{~h}$. The samples were weighed after being cooled at room temperature in desiccators.

Total lipid and fatty acid contents: The total lipids were extracted according to the method of Folch et al. (1957) and lipid contents were determined gravimetrically from nine samples per crossbred. Total lipids were converted to fatty acid methyl esters. Fatty acid methyl esters were separated and quantified by an automated gas chromatography (Agilent Technologies, Model 6890N, Santa Clara, CA, USA) equipped with flame ionization detectors and a 30 m×530 um i.d. capillary column (Agilent Technologies, Model HP-FFAP, Santa Clara, CA, USA). The Hewlett Packard Chem Station was used to integrate peak areas.

After getting individual fatty acids, the concentration of saturated fatty acids (SFA), unsaturated fatty acids (UFA), monounsaturated fatty acids (MUFA), and polyunsaturated fatty acids (PUFA) were calculated. The value of total SFA was calculated by adding the analyzed values of myristic acid, palmitic acid, and stearic acid. Similarly, the UFA was obtained by adding the analyzed values of palmitoleic acid, oleic acid, vaccenic acid, linoleic acid (Lino-A), $\gamma$ linoleicacid ( $\gamma$-Lino-A), linolenic acid (Linc-A), eicosenoic acid (Eico-A) and arachidonic acid (Arac-A). The MUFA was calculated by adding analyzed palmitoleic acid, oleic acid, vaccenic acid and eicosenoic acid values. The PUFA concentration was obtained by collecting values of Lino-A, $\gamma$-Lino-A, Linc-A, and Arac-A. Then the ratio between SFA and PUFA (SFA:PUFA) was calculated by dividing SFA with PUFA.

Total protein and amino acid composition: The level of amino acids in the muscles was related to $100 \%$ of dry weight. The nine breast samples were taken for the AA analysis. After acid hydrolysis of muscles in $6 \mathrm{~N} \mathrm{HCl}$ at $110^{\circ} \mathrm{C}$ for 24 hours the levels of amino acids were determined on the basis of a color reaction between an amino acid and ninhydrine (oxidizing agent) using an automatic amino-acid analyzer (L-8900 manufactured by Hitachi High-Technologies Corporation, Tokyo, Japan)(Watts, 2006). The following amino acids were monitored: cysteine (Cys), methionine (Met), aspartic acid (Asp), threonine (Thr), serine (Ser), glutamic acid (Glu), glycine (Gly), proline (Pro), alanine (Ala), valine (Val), isoleucine (Ile), leucine (Leu), tyrosine (Tyr), phenylalanine (Phe), histidine (His), lysine (Lys) and arginine (Arg).

The amino acids were then categorized as essential amino acid (EAA) and non-essential amino acid (NEAA). The EAA was constituted by adding the analyzed values of Cys, Met, Thr, Val, Ile, Leu, Tyr, Phe, Lys, and His whereas the NEAA were calculated by adding Asp, Ser, Glu, Gly, Ala, Arg and Pro. Further, the ratio between EAA and NEAA (EAA:NEAA) was calculated by dividing EAA with 
Table 2. Livability of commercial Korean native ducks during the experimental period

\begin{tabular}{lcccc}
\hline Crossbreds $^{1}$ & \multicolumn{4}{c}{ Livability (\%) } \\
\cline { 2 - 5 } & 0 to $2 \mathrm{wk}$ & 0 to $4 \mathrm{wk}$ & 0 to $6 \mathrm{wk}$ & 0 to 8 wk \\
\hline AA & $91.7 \pm 6.01^{2}$ & $91.7 \pm 6.01$ & $91.7 \pm 6.01$ & $91.7 \pm 6.01$ \\
AB & $100.0 \pm 0.00$ & $94.4 \pm 5.57$ & $91.1 \pm 4.85$ & $91.1 \pm 4.85$ \\
BB & $100.0 \pm 0.00$ & $98.6 \pm 1.41$ & $97.2 \pm 1.41$ & $97.2 \pm 1.41$ \\
BA & $91.7 \pm 4.82$ & $86.1 \pm 2.81$ & $86.1 \pm 2.81$ & $86.1 \pm 2.81$ \\
Means & $95.8 \pm 2.07^{3}$ & $92.7 \pm 2.32$ & $91.5 \pm 2.14$ & $91.5 \pm 2.14$ \\
\hline
\end{tabular}

SD, standard deviation.

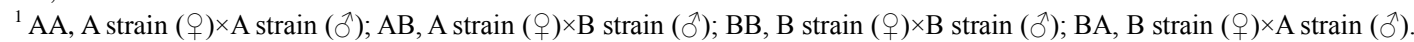

${ }^{2}$ Values are means \pm SD of 3 replicate pens ( 15 birds per pen).

${ }^{3}$ Value are means \pm SD of 12 replicate pens ( 15 birds per pen).

NEAA.

\section{Statistical analysis}

The data from this work was analyzed using the General Linear Model of the Statistical Analysis Systems (SAS, 2003). Duncan's multiple range test (Duncan, 1955) was used to make comparison of means. Each pen was designated as the experimental unit. The level of significance was $<0.05$ or otherwise stated.

\section{RESULTS}

\section{Livability}

Table 2 shows the livability of the KND large type used in this experiment. There was no significant difference between either different crossbreds or with increasing age $(\mathrm{p}>0.05)$

\section{Body weight and uniformity}

Body weight and uniformity of KND large type are shown in Table 3 and 4, respectively. At the start of the experiment (i.e. $0 \mathrm{wk}$ ), the BW of all the KND crossbreds was different $(\mathrm{p}<0.05)$. The crossbred BA had the highest BW (53.7 g) whereas crossbred $\mathrm{AB}$ had the lowest BW $(50.1 \mathrm{~g})$. At the end of $2 \mathrm{nd} w \mathrm{w}$, none of the KND crossbreds showed any difference in BW ( $>>0.05)$. Afterwards, crossbred $\mathrm{BB}$ gained the highest $\mathrm{BW}$ among all the crossbreds in the rest of the intervals observed $(\mathrm{p}<0.05)$. Lowest $\mathrm{BW}$ was observed in crossbred $\mathrm{AB}$ during 4th and 6th wk while crossbred AA showed lowest BW in 8th wk $(\mathrm{p}<0.05)$. The obvious significant rise in BW was observed with increasing age $(\mathrm{p}<0.05)$.

The uniformity (\%) was found unaffected among all the KND crossbreds $(p>0.05)$. However, there is a decline in uniformity (\%) of KND crossbreds with increasing age $(\mathrm{p}<0.05)$. The highest uniformity $(\%)$ was observed during

Table 4. Uniformity of commercial Korean native ducks at 6, 7, and 8 wk

\begin{tabular}{|c|c|c|c|}
\hline \multirow{2}{*}{ Crossbreds $^{1}$} & \multicolumn{3}{|c|}{ Uniformity (\%) } \\
\hline & 6wk & $7 \mathrm{wk}$ & $8 \mathrm{wk}$ \\
\hline $\mathrm{AA}$ & $82.2 \pm 2.23^{2}$ & $82.1 \pm 0.61$ & $77.9 \pm 1.49$ \\
\hline $\mathrm{AB}$ & $85.2 \pm 1.87$ & $83.3 \pm 8.33$ & $70.4 \pm 10.3$ \\
\hline BB & $87.6 \pm 3.31$ & $79.5 \pm 2.92$ & $78.2 \pm 5.75$ \\
\hline BA & $84.7 \pm 3.23$ & $76.8 \pm 2.16$ & $63.6 \pm 3.72$ \\
\hline Means & $84.9 \pm 1.31^{\mathrm{A} 3}$ & $80.5 \pm 2.08^{\mathrm{A}}$ & $72.5 \pm 3.22^{\mathrm{B}}$ \\
\hline \multicolumn{4}{|c|}{ 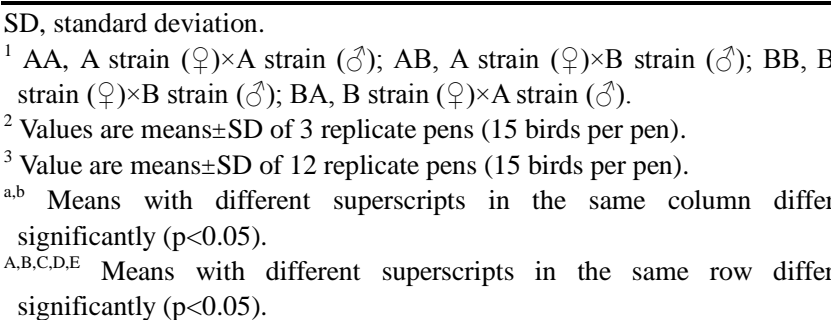 } \\
\hline
\end{tabular}

Table 3. Average body weight of commercial Korean native ducks during the experimental period

\begin{tabular}{lllccc}
\hline Crossbreds $^{1}$ & \multicolumn{5}{c}{ Body weight (g) } \\
\cline { 2 - 6 } & 0 & $2 \mathrm{wk}$ & $4 \mathrm{wk}$ & $6 \mathrm{wk}$ & $8 \mathrm{wk}$ \\
\hline AA & $52.3 \pm 0.65^{\mathrm{ab} 2}$ & $614 \pm 11.9$ & $1,626 \pm 11.1^{\mathrm{ab}}$ & $2,441 \pm 22.4^{\mathrm{bc}}$ & $2,762 \pm 30.5^{\mathrm{b}}$ \\
$\mathrm{AB}$ & $50.1 \pm 0.88^{\mathrm{b}}$ & $633 \pm 7.77$ & $1,575 \pm 16.3^{\mathrm{b}}$ & $2,376 \pm 15.1^{\mathrm{c}}$ & $2,807 \pm 40.3^{\mathrm{ab}}$ \\
BB & $52.0 \pm 1.05^{\mathrm{ab}}$ & $633 \pm 2.49$ & $1,644 \pm 7.82^{\mathrm{a}}$ & $2,573 \pm 95.1^{\mathrm{a}}$ & $2,949 \pm 42.5^{\mathrm{a}}$ \\
BA & $53.7 \pm 0.12^{\mathrm{a}}$ & $621 \pm 16.1$ & $1,621 \pm 22.5^{\mathrm{ab}}$ & $2,474 \pm 48.2^{\mathrm{b}}$ & $2,830 \pm 55.1^{\mathrm{ab}}$ \\
Means & $52.1 \pm 0.51^{\mathrm{E} 3}$ & $625 \pm 5.22^{\mathrm{D}}$ & $1,617 \pm 10.1^{\mathrm{C}}$ & $2,466 \pm 24.5^{\mathrm{B}}$ & $2,836 \pm 27.8^{\mathrm{A}}$ \\
\hline
\end{tabular}

SD, standard deviation.

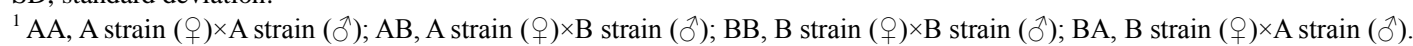

${ }^{2}$ Values are means \pm SD of 3 replicate pens ( 15 birds per pen).

${ }^{3}$ Value are means \pm SD of 12 replicate pens ( 15 birds per pen).

${ }^{a, b}$ Means with different superscripts in the same column differ significantly $(p<0.05)$.

$\mathrm{A}, \mathrm{B}, \mathrm{C}, \mathrm{D}, \mathrm{E}$ Means with different superscripts in the same row differ significantly $(\mathrm{p}<0.05)$. 
6th wk whereas the lowest uniformity $(\%)$ was noticed in 8 th wk $(\mathrm{p}<0.05)$.

Body weight gain, feed intake and feed conversion ratio

Body weight gain, FI, and FCR, of KND large type are shown in Table 5. The BWG was found unaffected among all the KND crossbreds during 0 to 2, 2 to 4 , and 6 to 8 wks ( $p>0.05$ ), however, crossbred BB showed the highest BWG during 4 to 6 wk $(929 \mathrm{~g})$ and 0 to 8 wk $(2,897 \mathrm{~g}$; $\mathrm{p}<0.05)$. However, when different experimental periods were compared for the BWG, it was found that KND gained maximum BW during 2 to $4 \mathrm{wk}$ and lowest during 6 to 8 wk $(\mathrm{p}<0.05)$.

All the crossbred KND did not show any difference in FI during 0 to 2 and 6 to 8 wks ( $>>0.05$ ). However, crossbreds AA and BB showed maximum FI during 2 to 4 wks whereas only crossbred $\mathrm{BB}$ showed maximum FI during 4 to 6 and 0 to 8 wks $(p<0.05)$. The crossbred KND showed a linear rise in FI with increasing age, with minimum FI in 0 to $2 \mathrm{wk}$ whereas maximum FI in 6 to $8 \mathrm{wk}$ $(\mathrm{p}<0.05)$.

The data of FCR for different KND crossbreds did not show any significant difference $(\mathrm{p}>0.05)$, however, with increasing age a linear rise in FCR was noticed among different crossbreds $(\mathrm{p}<0.05)$.

\section{Carcass yield}

Table 6 shows the carcass yield and partial meat ratio of various KND crossbreds used in the experiment. Except back weight ( $\mathrm{g}$ and $\%$ of live weight), the entire carcass traits were found similar among all crossbreds. Crossbred BB showed maximum back weight ( $\mathrm{g}$ and $\%$ of live weight) as compared to other crossbreds $(\mathrm{p}<0.05)$.

\section{Meat color and quality characteristics}

Meat color characteristics such as Lightness (L*), redness $\left(a^{*}\right)$, yellowness $\left(b^{*}\right)$, and quality characteristics such as cooking loss, water holding capacity and shear force are presented in Table 7. Except cooking loss, all the meat color and quality characteristics were not affected across all the crossbreds. Cooking loss (\%) was highest in BA crossbred as compared to other crossbreds $(\mathrm{p}<0.05)$.

\section{Chemical composition of meat}

The data related to the chemical content analysis of breast meat is presented in Table 8 and remained similar in all the crossbreds $(\mathrm{p}>0.05)$.

\section{Fatty acid composition of meat}

The fatty acid composition of broiler meat is presented in Table 9. The composition of all the fatty acids, except Eico-A, was found non-significant in all the crossbreds. The

Table 5. Body weight gain, feed intake and feed conversion ratio of commercial Korean native ducks during experimental period

\begin{tabular}{|c|c|c|c|c|c|}
\hline \multirow{2}{*}{ Crossbreds $^{1}$} & \multicolumn{4}{|c|}{ Weeks } & \multirow{2}{*}{$\begin{array}{c}\text { Average } \\
(0 \text { to } 8 \mathrm{wk})\end{array}$} \\
\hline & 0 to $2 \mathrm{wk}$ & 2 to $4 \mathrm{wk}$ & 4 to $6 \mathrm{wk}$ & 6 to $8 \mathrm{wk}$ & \\
\hline & \multicolumn{5}{|c|}{ 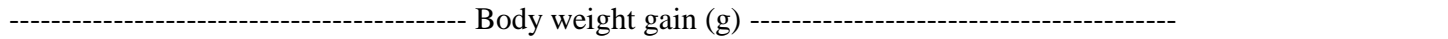 } \\
\hline AA & $562 \pm 11.4^{2}$ & $1,012 \pm 18.3$ & $815 \pm 16.9^{b}$ & $321 \pm 13.2$ & $2,710 \pm 30.5^{\mathrm{b}}$ \\
\hline $\mathrm{AB}$ & $583 \pm 8.6$ & $941.9 \pm 19.1$ & $802 \pm 19.7^{b}$ & $430 \pm 51.3$ & $2,757 \pm 40.7^{\mathrm{ab}}$ \\
\hline $\mathrm{BB}$ & $581 \pm 3.5$ & $1,012 \pm 5.37$ & $929 \pm 8.1^{\mathrm{a}}$ & $376 \pm 51.7$ & $2,897 \pm 42.4^{\mathrm{a}}$ \\
\hline BA & $577 \pm 15.9$ & $1,000 \pm 38.3$ & $852 \pm 25.8^{b}$ & $356 \pm 27.1$ & $2,776 \pm 55.3^{\mathrm{ab}}$ \\
\hline Means & $573 \pm 5.4^{\mathrm{C} 3}$ & $991.5 \pm 13.2^{\mathrm{A}}$ & $850 \pm 16.9^{\mathrm{B}}$ & $371 \pm 20.6^{\mathrm{D}}$ & $2,785 \pm 27.8$ \\
\hline AA & $672 \pm 12.9^{2}$ & $1,940 \pm 16.5^{\mathrm{a}}$ & (g) & $3,407 \pm 222.9$ & $8,851 \pm 223.8^{\mathrm{ab}}$ \\
\hline $\mathrm{AB}$ & $659 \pm 8.9$ & $1,755 \pm 25.2^{\mathrm{b}}$ & $2,675 \pm 29.9^{b}$ & $3,379 \pm 99.6$ & $8,468 \pm 118.1^{b}$ \\
\hline $\mathrm{BB}$ & $667 \pm 4.9$ & $1,924 \pm 37.9^{\mathrm{a}}$ & $3,016 \pm 83.1^{\mathrm{a}}$ & $3,522 \pm 79.8$ & $9,129 \pm 198.6^{\mathrm{a}}$ \\
\hline BA & $678 \pm 4.6$ & $1,737 \pm 10.3^{\mathrm{b}}$ & $2,725 \pm 70.3^{\mathrm{b}}$ & $3,217 \pm 78.5$ & $8,358 \pm 155.2^{b}$ \\
\hline Means & $669 \pm 4.2^{\mathrm{D} 3}$ & $1,839 \pm 30.1^{\mathrm{C}}$ & $2,812 \pm 47.2^{\mathrm{B}}$ & $3,381 \pm 65.9^{\mathrm{A}}$ & $8,701 \pm 120.8$ \\
\hline & & --- Feec & ion ratio ------ & 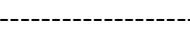 & \\
\hline AA & $1.20 \pm 0.03^{2}$ & $1.92 \pm 0.05$ & $3.47 \pm 0.02$ & $10.6 \pm 0.37$ & $3.26 \pm 0.05$ \\
\hline $\mathrm{AB}$ & $1.13 \pm 0.03$ & $1.86 \pm 0.02$ & $3.34 \pm 0.11$ & $8.01 \pm 0.66$ & $3.07 \pm 0.01$ \\
\hline $\mathrm{BB}$ & $1.15 \pm 0.01$ & $1.90 \pm 0.04$ & $3.25 \pm 0.06$ & $9.75 \pm 1.42$ & $3.15 \pm 0.11$ \\
\hline BA & $1.20 \pm 0.03$ & $1.74 \pm 0.08$ & $3.219 \pm 0.1$ & $9.12 \pm 0.61$ & $3.01 \pm 0.11$ \\
\hline Means & $1.17 \pm 0.01^{\mathrm{D} 3}$ & $1.86 \pm 0.03^{\mathrm{C}}$ & $3.32 \pm 0.06^{\mathrm{B}}$ & $9.37 \pm 0.46^{\mathrm{A}}$ & $3.13 \pm 0.04$ \\
\hline
\end{tabular}

SD, standard deviation.

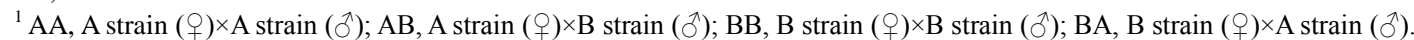

${ }^{2}$ Values are means \pm SD of 3 replicate pens ( 15 birds per pen).

${ }^{3}$ Value are means \pm SD of 12 replicate pens ( 15 birds per pen).

${ }^{\mathrm{a}, \mathrm{b}}$ Means with different superscripts in the same column differ significantly $(\mathrm{p}<0.05)$

A,B,C,D Means with different superscripts in the same row differ significantly $(\mathrm{p}<0.05)$. 
Table 6. Carcass yield and partial meat ratio of commercial Korean native ducks

\begin{tabular}{lcccc}
\hline \multirow{2}{*}{ Item } & \multicolumn{4}{c}{ Crossbreds $^{1}$} \\
\cline { 2 - 5 } & AA & AB & BB & BA \\
\hline Live weight (g) & $3,000 \pm 48.6^{\mathrm{b} 2}$ & $3,092 \pm 13.2^{\mathrm{ab}}$ & $3,263 \pm 105.8^{\mathrm{a}}$ & $3,152 \pm 80.6^{\mathrm{ab}}$ \\
Carcass weight (g) & $2,208 \pm 25.2$ & $2,213 \pm 24.6$ & $2,398 \pm 100.4$ & $2,260 \pm 75.1$ \\
Partial meat weight & & & $315.0 \pm 17.6$ \\
Wing (g) & $290.0 \pm 10.4$ & $293.3 \pm 6.01$ & $308.3 \pm 16.4$ & $553.3 \pm 14.2^{\mathrm{ab}}$ \\
Back (g) & $528.3 \pm 20.3^{\mathrm{ab}}$ & $488.3 \pm 17.6^{\mathrm{b}}$ & $588.3 \pm 29.6^{\mathrm{a}}$ & $273.3 \pm 18.8$ \\
Neck (g) & $278.3 \pm 16.7$ & $305.0 \pm 11.6$ & $280.0 \pm 12.6$ & $653.3 \pm 24.6$ \\
Breast (g) & $660.0 \pm 16.1$ & $660.0 \pm 20.2$ & $738.3 \pm 36.1$ & $465.0 \pm 18.3$ \\
Leg (g) & $451.7 \pm 10.9$ & $466.7 \pm 11.7$ & $483.3 \pm 33.5$ & $71.7 \pm 0.65$ \\
Carcass yield (\%) & $73.6 \pm 0.64$ & $71.6 \pm 0.51$ & $73.5 \pm 0.91$ & \\
Partial meat ratio & & & & $9.98 \pm 0.33$ \\
Wing (\%) & $9.66 \pm 0.19$ & $9.49 \pm 0.15$ & $18.0 \pm 0.39^{\mathrm{a}}$ & $17.6 \pm 0.21^{\mathrm{a}}$ \\
Back (\%) & $17.6 \pm 0.71^{\mathrm{a}}$ & $15.8 \pm 0.51^{\mathrm{b}}$ & $8.61 \pm 0.59$ & $8.65 \pm 0.38$ \\
Neck (\%) & $9.28 \pm 0.53$ & $9.86 \pm 0.36$ & $22.6 \pm 0.64$ & $20.7 \pm 0.81$ \\
Breast (\%) & $22.0 \pm 0.27$ & $21.4 \pm 0.64$ & $14.8 \pm 0.61$ & $14.7 \pm 0.21$ \\
Leg (\%) & $15.1 \pm 0.61$ & $15.1 \pm 0.42$ & & \\
\hline
\end{tabular}

$\mathrm{SD}$, standard deviation.

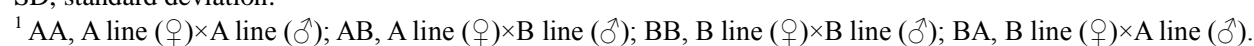

${ }^{2}$ Values are means $\pm \mathrm{SD}$ of 3 replicates of 3 birds each.

${ }^{a, b}$ Means with different superscripts in the same column differ significantly $(\mathrm{p}<0.05)$

Table 7. Breast meat color and quality characteristics of commercial Korean native ducks ${ }^{1}$

\begin{tabular}{|c|c|c|c|c|}
\hline \multirow{2}{*}{ Item } & \multicolumn{4}{|c|}{ Crossbreds $^{2}$} \\
\hline & AA & $\mathrm{AB}$ & $\mathrm{BB}$ & BA \\
\hline \multicolumn{5}{|l|}{$\overline{\mathrm{CIE}}$} \\
\hline Lightness (L*) & $37.9 \pm 0.41^{3}$ & $38.4 \pm 0.08$ & $39.0 \pm 0.61$ & $39.1 \pm 0.89$ \\
\hline Redness $\left(a^{*}\right)$ & $17.8 \pm 0.99$ & $17.3 \pm 0.14$ & $18.8 \pm 0.91$ & $17.3 \pm 0.69$ \\
\hline Yellowness $\left(b^{*}\right)$ & $6.91 \pm 0.82$ & $6.24 \pm 0.17$ & $7.26 \pm 0.86$ & $7.08 \pm 0.49$ \\
\hline Cooking loss $(\%)$ & $25.3 \pm 0.51^{\mathrm{b}}$ & $25.5 \pm 0.42^{\mathrm{b}}$ & $24.5 \pm 0.33^{\mathrm{b}}$ & $26.7 \pm 0.18^{\mathrm{a}}$ \\
\hline Water holding capacity (\%) & $59.6 \pm 0.25$ & $60.6 \pm 1.02$ & $61.6 \pm 1.15$ & $58.3 \pm 0.96$ \\
\hline Shear force $\left(\mathrm{kg} / \mathrm{cm}^{2}\right)$ & $1.94 \pm 0.25$ & $1.76 \pm 0.17$ & $1.89 \pm 0.16$ & $2.05 \pm 0.13$ \\
\hline
\end{tabular}

CIE, Commision Internationale de Leclairage; SD, standard deviation.

${ }^{1}$ Number of observations per mean value $=9$ ( 3 ducks $\times 3$ replicates $)$.

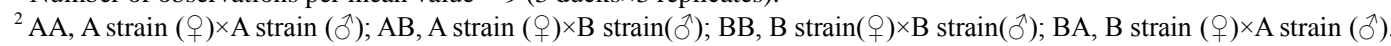

${ }^{3}$ Values are means \pm SD of 3 replicates of 3 birds each.

${ }^{\mathrm{a}, \mathrm{b}}$ Means with different superscripts in the same column differ significantly $(\mathrm{p}<0.05)$.

Table 8. Chemical composition of meat of commercial Korean native ducks ${ }^{1}$

\begin{tabular}{lcccc}
\hline Items & \multicolumn{3}{c}{ Crossbreds $^{2}$} \\
\cline { 2 - 5 } & $\mathrm{AA}$ & $\mathrm{AB}$ & $\mathrm{BB}$ & $\mathrm{BA}$ \\
\hline $\mathrm{pH}$ & $5.99 \pm 0.04^{3}$ & $5.98 \pm 0.02$ & $6.02 \pm 0.01$ & $5.92 \pm 0.04$ \\
Moisture (\%) & $75.2 \pm 0.07$ & $75.1 \pm 0.13$ & $75.1 \pm 0.21$ & $75.7 \pm 0.45$ \\
Fat (\%) & $1.52 \pm 0.09$ & $1.83 \pm 0.26$ & $1.92 \pm 0.24$ & $1.59 \pm 0.32$ \\
Protein (\%) & $20.9 \pm 0.07$ & $20.9 \pm 0.13$ & $20.8 \pm 0.09$ & $20.5 \pm 0.37$ \\
Ash (\%) & $1.11 \pm 0.01$ & $1.08 \pm 0.04$ & $1.08 \pm 0.04$ & $1.13 \pm 0.01$ \\
\hline
\end{tabular}

$\mathrm{SD}$, standard deviation.

${ }^{1}$ Number of observations per mean value $=9$ ( 3 ducks $\times 3$ replicates $)$.

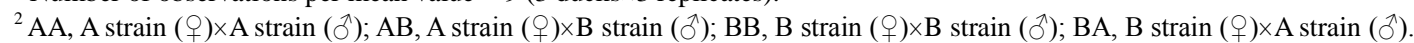

${ }^{3}$ Values are means \pm SD of 3 replicates of 3 birds each.

${ }^{a, b, c}$ Means with different superscripts in the same column differ significantly $(\mathrm{p}<0.05)$. 
Table 9. Fatty acid composition (\%) of breast meat of commercial Korean native ducks ${ }^{1}$

\begin{tabular}{lcccc}
\hline \multirow{2}{*}{ Index } & \multicolumn{3}{c}{ Crossbreds $^{2}$} \\
\cline { 2 - 5 } & $\mathrm{AA}$ & $\mathrm{AB}$ & $\mathrm{BB}$ & $0.60 \pm 0.02$ \\
\hline Myri-A & $0.57 \pm 0.02^{3}$ & $0.59 \pm 0.04$ & $21.9 \pm 0.15$ & $21.6 \pm 0.12$ \\
Palm-A & $21.9 \pm 0.53$ & $21.7 \pm 0.26$ & $3.41 \pm 0.233$ & $3.19 \pm 0.18$ \\
Palc-A & $3.08 \pm 0.09$ & $2.87 \pm 0.11$ & $6.97 \pm 0.21$ & $7.12 \pm 0.09$ \\
Stea-A & $7.33 \pm 0.11$ & $7.02 \pm 0.31$ & $45.1 \pm 0.33$ & $44.9 \pm 0.15$ \\
Olei-A & $44.6 \pm 1.56$ & $45.4 \pm 1.11$ & $18.4 \pm 0.69$ & $18.9 \pm 0.16$ \\
Lino-A & $18.9 \pm 0.81$ & $19.0 \pm 0.51$ & $0.08 \pm 0.01$ & $0.09 \pm 0.01$ \\
Linc-A & $0.09 \pm 0.02$ & $0.84 \pm 0.02$ & $0.84 \pm 0.04$ \\
$\gamma$-Lino-A & $0.84 \pm 0.04$ & $0.50 \pm 0.02^{\mathrm{a}}$ & $0.82 \pm 0.03$ & $0.45 \pm 0.01^{\mathrm{b}}$ \\
Eico-A & $0.52 \pm 0.00^{\mathrm{a}}$ & $1.95 \pm 0.15$ & $2.25 \pm 0.09$ & $2.41 \pm 0.14$ \\
Arac-A & $2.23 \pm 0.18$ & $29.3 \pm 0.52$ & $29.5 \pm 0.06$ & $29.3 \pm 0.06$ \\
SFA & $29.8 \pm 0.61$ & $48.8 \pm 1.18$ & $49.0 \pm 0.65$ & $48.5 \pm 0.14$ \\
MUFA & $48.2 \pm 1.65$ & $21.9 \pm 0.66$ & $21.5 \pm 0.64$ & $22.2 \pm 0.08$ \\
PUFA & $22.0 \pm 1.02$ & $70.7 \pm 0.52$ & $70.5 \pm 0.06$ & $70.7 \pm 0.06$ \\
UFA & $70.2 \pm 0.61$ & $0.75 \pm 0.01$ & $0.73 \pm 0.02$ & $0.76 \pm 0.01$ \\
PUFA:SFA & $0.74 \pm 0.02$ & $1.67 \pm 0.07$ & $1.66 \pm 0.02$ & $1.65 \pm 0.01$ \\
MUFA:SFA & $1.62 \pm 0.09$ & ab & \\
\hline
\end{tabular}

Myri-A, myristic acid; Palm-A, palmitic acid; Stea-A, stearic acid; Palc-A, palmitoleic acid; Olei-A, oleic acid; Vac-A, vaccenic acid; Lino-A, linoleic acid; $\gamma$-Lino-A, $\gamma$-linoleic acid; Linc-A, linolenic acid; Eico-A, eicosenoic acid; Arac-A, arachidonic acid; SFA, saturated fatty acids; MUFA, monounsaturated fatty acids; PUFA, polyunsaturated fatty acids; UFA, unsaturated fatty acid (MUFA+PUFA); PUFA:SFA, ratio between PUFA and SFA; MUFA:SFA, ratio between MUFA and SFA; SD, standard deviation.

${ }^{1}$ Number of observations per mean value $=9$ ( 3 ducks $\times 3$ replicates $)$.

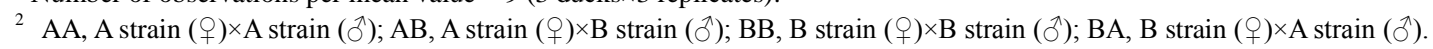

${ }^{3}$ Values are means $\pm \mathrm{SD}$ of 3 replicates of 3 birds each.

${ }^{a, b}$ Means with different superscripts in the same column differ significantly $(\mathrm{p}<0.001)$.

crossbred BA had shown lowest concentration of Eico-A in breast meat when compared with other crossbreds $(\mathrm{p}<0.05)$. The collective values of fatty acids (i.e. SFA, MUFA, PUFA, UFA) and their ratios were also not affected among all the crossbreds $(\mathrm{p}>0.05)$.

\section{Amino acid composition of meat}

The analyzed values of amino acids of broiler meat samples are presented in Table 10. Among essential and non-essential amino acids, the concentration of valine and glycine were found highest in crossbred $\mathrm{AB}$ and lowest in crossbred BA. Rest of the amino acids were found unaffected among all the crossbreds.

\section{DISCUSSION}

It is anticipated that the livability of ducks will not decrease significantly unless the ducklings were reared in poor environmental conditions. In this experiment, the livability of KND crossbreds was over $90 \%$ which implies that relatively good housing facilities and environment were provided to the birds. In terms of the performance, BW of $\mathrm{BB}$ crossbred was higher than other crossbreds irrespective of the higher initial BW of crossbred BA. It means that initial weight does not have any relation to the growth potential of crossbreds. Moreover, crossbreds did not show an unusual growth pattern with increasing age. This is similar to the results of Hong et al. (2012) who reported that B line showed higher BW as compared to A line. The initial higher $\mathrm{BW}$ of BA crossbred as compared to $\mathrm{AB}$ crossbred might be due the fact that BA crossbred used $\mathrm{B}$ line that has higher productivity as a female rather than A line which has lower productivity (Kim et al., 2012; Hong et al., 2012). The weekly BW of commercial Pekin duck which were reported in the previous research are around $650 \mathrm{~g}$ at $2 \mathrm{wk}$ old (Lee and Lee, 2005; Bang et al., 2010), 2,000 g at 4 wkold (Lee and Lee, 2005; Bang et al., 2010), 3,000 g at 6-wk old (Farhat and Chavez, 2000; Adeola, 2003; Lee and Lee, 2005; Bang et al., 2010), and 3,700 g at 8-wk old (Bang et al., 2010; Kim et al., 2010). Generally the BW of KND is much lower than that of commercial meat type duck. The overall BW of crossbred KND in the present study were also lower than commercial meat type duck although there was significant difference among the crossbreds.

The lowest uniformity (\%) at the age of $8 \mathrm{wk}$ among all crossbreds showed that weight gain pattern of birds against FI might change that further changed uniformity of different crossbreds at this age. This is also obvious from an abrupt decline in BWG at the end of $8 \mathrm{wk}$. Hong et al. (2012) and Kim et al. (2012) reported that the BW of KND between male and female were similar until 7 wk-old but differed from 8 wk-old. In this experiment, males and females were 
Table 10. Amino acid composition (\%) of breast meat of commercial Korean native ducks ${ }^{1}$

\begin{tabular}{|c|c|c|c|c|}
\hline \multirow{2}{*}{ Index } & \multicolumn{4}{|c|}{ Crossbreds $^{2}$} \\
\hline & AA & $\mathrm{AB}$ & $\mathrm{BB}$ & $\mathrm{BA}$ \\
\hline \multicolumn{5}{|l|}{ Essential } \\
\hline Histidine & $0.58 \pm 0.01^{3}$ & $0.61 \pm 0.02$ & $0.62 \pm 0.01$ & $0.60 \pm 0.01$ \\
\hline Isoleucine & $0.84 \pm 0.01$ & $0.87 \pm 0.03$ & $0.84 \pm 0.01$ & $0.82 \pm 0.02$ \\
\hline Leucine & $1.76 \pm 0.02$ & $1.76 \pm 0.02$ & $1.76 \pm 0.01$ & $1.73 \pm 0.03$ \\
\hline Lysine & $1.74 \pm 0.02$ & $1.74 \pm 0.01$ & $1.75 \pm 0.01$ & $1.73 \pm 0.04$ \\
\hline Methionine & $0.49 \pm 0.01$ & $0.51 \pm 0.00$ & $0.49 \pm 0.01$ & $0.49 \pm 0.01$ \\
\hline Phenylalanine & $0.83 \pm 0.01$ & $0.82 \pm 0.01$ & $0.82 \pm 0.00$ & $0.81 \pm 0.01$ \\
\hline Threonine & $0.96 \pm 0.01$ & $0.96 \pm 0.01$ & $0.96 \pm 0.00$ & $0.94 \pm 0.02$ \\
\hline Valine & $0.85 \pm 0.02^{\mathrm{ab}}$ & $0.90 \pm 0.01^{\mathrm{a}}$ & $0.86 \pm 0.01^{\mathrm{ab}}$ & $0.84 \pm 0.01^{\mathrm{b}}$ \\
\hline \multicolumn{5}{|l|}{ Nonessential } \\
\hline Arginine & $1.26 \pm 0.01$ & $1.26 \pm 0.01$ & $1.28 \pm 0.01$ & $1.27 \pm 0.02$ \\
\hline Alanine & $1.25 \pm 0.01$ & $1.25 \pm 0.00$ & $1.25 \pm 0.00$ & $1.22 \pm 0.02$ \\
\hline Aspartic acid & $1.91 \pm 0.02$ & $1.92 \pm 0.01$ & $1.92 \pm 0.01$ & $1.89 \pm 0.03$ \\
\hline Cystine & $0.22 \pm 0.00$ & $0.23 \pm 0.00$ & $0.22 \pm 0.01$ & $0.22 \pm 0.00$ \\
\hline Glutamic acid & $3.20 \pm 0.03$ & $3.24 \pm 0.03$ & $3.21 \pm 0.01$ & $3.20 \pm 0.05$ \\
\hline Glycine & $0.93 \pm 0.01^{\mathrm{ab}}$ & $0.94 \pm 0.02^{\mathrm{a}}$ & $0.93 \pm 0.01^{\mathrm{ab}}$ & $0.90 \pm 0.01^{\mathrm{b}}$ \\
\hline Proline & $0.75 \pm 0.01$ & $0.75 \pm 0.01$ & $0.74 \pm 0.00$ & $0.73 \pm 0.01$ \\
\hline Serine & $0.85 \pm 0.01$ & $0.85 \pm 0.00$ & $0.85 \pm 0.00$ & $0.83 \pm 0.01$ \\
\hline Tyrosine & $0.72 \pm 0.01$ & $0.72 \pm 0.01$ & $0.72 \pm 0.00$ & $0.70 \pm 0.01$ \\
\hline
\end{tabular}

SD, standard deviation.

${ }^{1}$ Number of observations per mean value $=9(3$ ducks $\times 3$ replicates $)$.

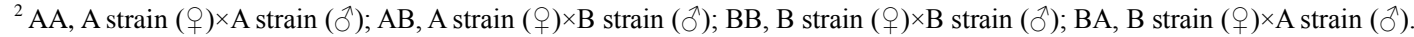

${ }^{3}$ Values are means \pm SD of 3 replicates of 3 birds each.

${ }^{a, b}$ Means with different superscripts in the same column differ significantly $(\mathrm{p}<0.05)$.

reared together. Due to this reason, it is assumed that the uniformity until the $7 \mathrm{wk}$ was high but decreased after $8 \mathrm{wk}$.

The maximum gain in weight during 2 to 4 wks irrespective of the crossbred showed that crossbreds had the highest potential of weight gain during this age whereas during 6 to $8 \mathrm{wk}$ the crossbreds showed a poor gain which depicts that the best slaughter age is before 6 th wk. The data of FI and FCR also highlighted this age as the best age for better growth and feed efficiency across all the crossbreds. The BWG of large type KND was lower when compared to that of commercial ducks in some previous research (NRC, 1994; Lee and Lee, 2005; Bang et al., 2010) and it was similar to the BWG of KND reported by Kim et al. (2012).

The FI of AA and $\mathrm{BB}$ (pure lines) was higher than $\mathrm{AB}$ and BA line until 6 wk but the significant difference disappeared during 6 to $8 \mathrm{wk}$. It is presumably related to lower BW of crossbred and requires further investigation. When the FI of large-type KND was compared to that of a commercial duck (NRC, 1994; Lee and Lee, 2005; Bang et al., 2010), it was found to be lower until 6 wk-old. However there was not much difference in FI between KND and commercial duck at 6 to 8 wk-old. Probably it is due to the fact that the growth of duck reaches a plateau at $6 \mathrm{wk}$ and after $6 \mathrm{wk}$, feed to gain gradually decreases.

There was no significant difference in FCR among crossbreds of the KND largest type used in this experiment.
Lee and Lee (2005) reported that FCR of commercial duck was 1.53 at 0 to $2 \mathrm{wk}, 1.91$ at 2 to $4 \mathrm{wk}, 5.83$ at 4 to $6 \mathrm{wk}$, and 2.84 at 0 to $6 \mathrm{wk}$. According to NRC (1994), FCR of female and male duck is 0.95 and 0.99 at 0 to $2 \mathrm{wk}, 3.33$ and 3.40 at 2 to $4 \mathrm{wk}, 6.35$ and 6.50 at 4 to $6 \mathrm{wk}, 9.61$ and 9.86 at 6 to $8 \mathrm{wk}$, and 4.71 and 4.78 at 0 to $8 \mathrm{wk}$ old, respectively. In the present study the FCR was lower up to 4 wk but became higher after $4 \mathrm{wk}$ than the results of Lee and Lee (2005) and the NRC (1994) recommendation. These results might be due to the fact that KND shows similar weight gain and low FI compared with commercial duck up to 4 wk old.

The FCR of KND large-type at 0 to 8 wk was 3.13 which was lower than the FCR of 3.70 reported by Kim et al. (2012). It shows that the ability of KND breed has been improved after selection and crossing breeding.

Among carcass traits, back weight was found highest in crossbred BB like other growth parameters. Carcass weights were similar to those of a commercial duck reported by Bang et al. (2010). But carcass ratio was higher than that reported by Bang et al. (2010). Partial meat yield (wing, back, neck, breast, leg) of KND large type was lower than those of a commercial duck reported by Bang et al. (2010).

Data on the chemical composition of KND meat is very scarce. However, in the present study the Eico-A was in 
lower concentration in BA group and highest in AA. The Eico-A is a component of polyunsaturated fatty acid. This finding designates the higher nutritional value of meat in terms of high PUFA in the AA crossbred and also showed a preference of health conscious consumers for this meat. The higher contents of glycine in $\mathrm{AB}$ crossbred meat show its higher retention in the meat rather excreted along with nitrogen in uric acid.

\section{CONCLUSION}

Crossbred BB showed highest BW, weight gain, FI, and back weight. Crossbred BA showed the lowest concentration of Eico-A, valine and glycine, and highest cooking loss whereas crossbred $\mathrm{AB}$ showed the highest concentration of valine and glycine. It can be inferred from growth and carcass responses of different crossbreds, the crossbred $\mathrm{BB}$ is one of the best choices for better growth and carcass yields. Further, a careful breeding plan should be devised so as to improve its efficiency comparable to commercial strains of duck.

\section{ACKNOWLEDGMENTS}

This work was carried out with the support of "Cooperative Research Program for Agriculture Science \& Technology Development (Project No. PJ907045)", Rural Development Administration, Republic of Korea.

\section{REFERENCES}

AOAC. 2005. Official Methods of Analysis. 18th ed. Association of Official Analytical Chemists, Washington, DC, USA.

Adeola, O. 2003. Recent advances in duck nutrition. 24 Western Nutrition Conference. September 10-11, 2003; Manitoba, Canada. pp. 191-204.

Bang, H. T., J. C. Na, H. C. Choi, H. S. Chae, H. K. Kang, D. W. Kim, M. J. Kim, O. S. Suh, S. B. Park, and Y. H. Choi. 2010. A comparative study on performances and carcass traits in three major meat-type duck strains in Korea. Korean J. Poult. Sci. 37:389-398.

Chae, H. S., H. C. Choi, J. C. Na, A. Jang, M. J. Kim, H. T. Bang, D. W. Kim, O. S. Seo, S. B. Park, S. H. Cho, and H. K. Kang. 2011. Effects of raising periods on physic-chemical meat properties of chicken. Korean J. Poult. Sci. 38:285-291.

Duncan, D. B. 1955. Multiple range and multiple F-tests. Biometrics 11:1-42.
Farhat, A. and E. R. Chavez. 2000. Comparative performance, blood chemistry, and carcass composition of two lines of Pekin ducks reared mixed or separated by sex. Poult. Sci. 79:460-465.

Folch, J., M. Lees, and G. H. A. Sloane-Stanley. 1957. A simple methods for the isolation and purification of total lipids from animal tissues. J. Biol. Chem. 226:497-507.

Hamm, R. 1961. Biochemistry of meat hydration. Adv. Food Res. 10:355-463.

Hong, E. C., H. J. Choo, B. S. Kang, C. D. Kim, K. N. Heo, M. J. Lee, J. Hwangbo, O. S. Suh, H. C. Choi, and H. K. Kim. 2012. Performance of growing period of large-type Korean native ducks. Korean J. Poult. Sci. 39:143-149.

Kang, G. H., T. C. Jeong, H. S. Yang, S. H. Kim, B. G. Jang, H. S. Kang, D. S. Lee, S. J. Lee, S. T. Joo, and G. B. Park. 2006. Effects of packaging methods on color and lipid oxidation of duck meat during cold storage. Korean J. Poult. Sci. 33:7-14.

Kim, H. K., B. S. Kang, J. Hwangbo, C. D. Kim, K. N. Heo, H. J. Choo, D. S. Park, O. S. Suh, and E. C. Hong. 2012. The study on growth performance and carcass yield of meat-type Korean native ducks. Korean J. Poult. Sci. 39:45-52.

Kim, H. K., E. C. Hong, B. S. Kang, M. N. Park, B. Y. Seo, H. J. Choo, S. H. Na, H. T. Bang, O. S. Suh, and J. Hwangbo. 2010. Effect of crossbreeding of Korean native duck and broiler ducks on performance and carcass yield. Korean J. Poult. Sci. 33:229-235.

Kim, K. S., M. K. Lee, W. J. Lee, Y. I. Choi, and S. K. Cho. 2011. Effect of dietary Astaxanthin producing Bacteria (Xanthophyllomyces dendrohous) on the growth performance and the meat quality of ducks. J. Anim. Sci. Tech. 53:139-146.

Korean Feeding Standard for Poultry. 2007. National Institute of Animal Science, Seonghwan, Cheonan, Korea.

Lee, W. J. and K. H. Lee. 2005. Effects of dietary Kaolin on the performance, product quality and feeding environment of growing ducks. Korean J. Poult. Sci. 32:81-87.

National Institute of Agricultural Science and Technology (NIAST). 2011. Food Composition Table, 8th version. pp. 326.

National Research Council. 1994. Nutrient Requirements of Poultry. 9th rev. ed. National Academy Press, Washington DC, USA.

Park, B. Y., J. M. Lee, and I. H. Hwang. 2007. Effect of postmortem metabolic rate on meat color. Asian Australas. J. Anim. Sci. 20:598-604.

Statistical Analysis System. 2003. Statistical Analysis System User's Guide, Statistics. Version 9.1. SAS Institute Inc., Cary, NC, USA.

Watts, S. T. 2006. Advancements in Amino Acid Analysis: Introduction of the New Hitachi L-8900 Amino Acid Analyzer. LCGC North America 24(Suppl):17-20

Zhuang, H., E. M. Savage, S. E. Kays, and D. S. Himmelsbach. 2007. A survey of the quality of six retail brands of boneless, skinless chicken breast fillets obtained from retail supermarkets in the Athens, Georgia area. J. Food Qual. 30:1068-1082. 